\title{
DISTRIBUTION AND ECOLOGY OF AUSTRALIAN SEDGE
}

B. P. J. Molloy, P. J. Rumball, and G. L. B. Cumberi.and Scientists, Department of Agriculture, Lincoln, Palmerston North, and Auckland

Australian sedge (Carex longebrachiata) is potentially a serious weed on North Island hill country which lacks a vigorous sward. Its recognition as a weed, acknowledged by its inclusion in the Noxious Weeds Act in 1962, was delayed until some infestations were completely out of control. This account summarizes existing information on this plant with particular reference to the northern part of New Zealand.

\section{BIOLOGICAL FEATURES}

\section{DESCRIPTION}

A densely tufted perennial forming deeply-rooted tussocks up to $3 \mathrm{ft}$ tall (Fig. 1). Leaves about $5 \mathrm{~mm}$ wide, Y-shaped in cross-section, often exceeding the flowering stems and gradually tapering to tips; edges harsh and inclined to cut. Basal sheaths dark brown and entire. Flowering stems triangular in cross-section and sharply angled. Flowers grouped in catkin-like spikes, most of which are female and hang at the end of long, thin, nodding stalks. Fruit $(=$ seed $)$ a small triangular nut, smooth and awnless, enclosed within a long-beaked utricle about $5 \mathrm{~mm}$ long. Leaves and flowering stems droop conspicuously.

\section{Relationships}

Carex longebrachiata is native to Australia and not closely related to other species of Carex found in N ew Zealand. Variation in size and seasonal activity is attributed to age and environment, and no field evidence has been found of genetically-determined variation between plants.

Australian sedge is distinguished from grasses and rushes by its harsh cutting leaves, angled flowering stems, and catkin-like spikes. It is separated from other species of Carex in New Zealand by its intravaginal tillering and distinctive inflorescence (Molloy and Edgar, 1967). 


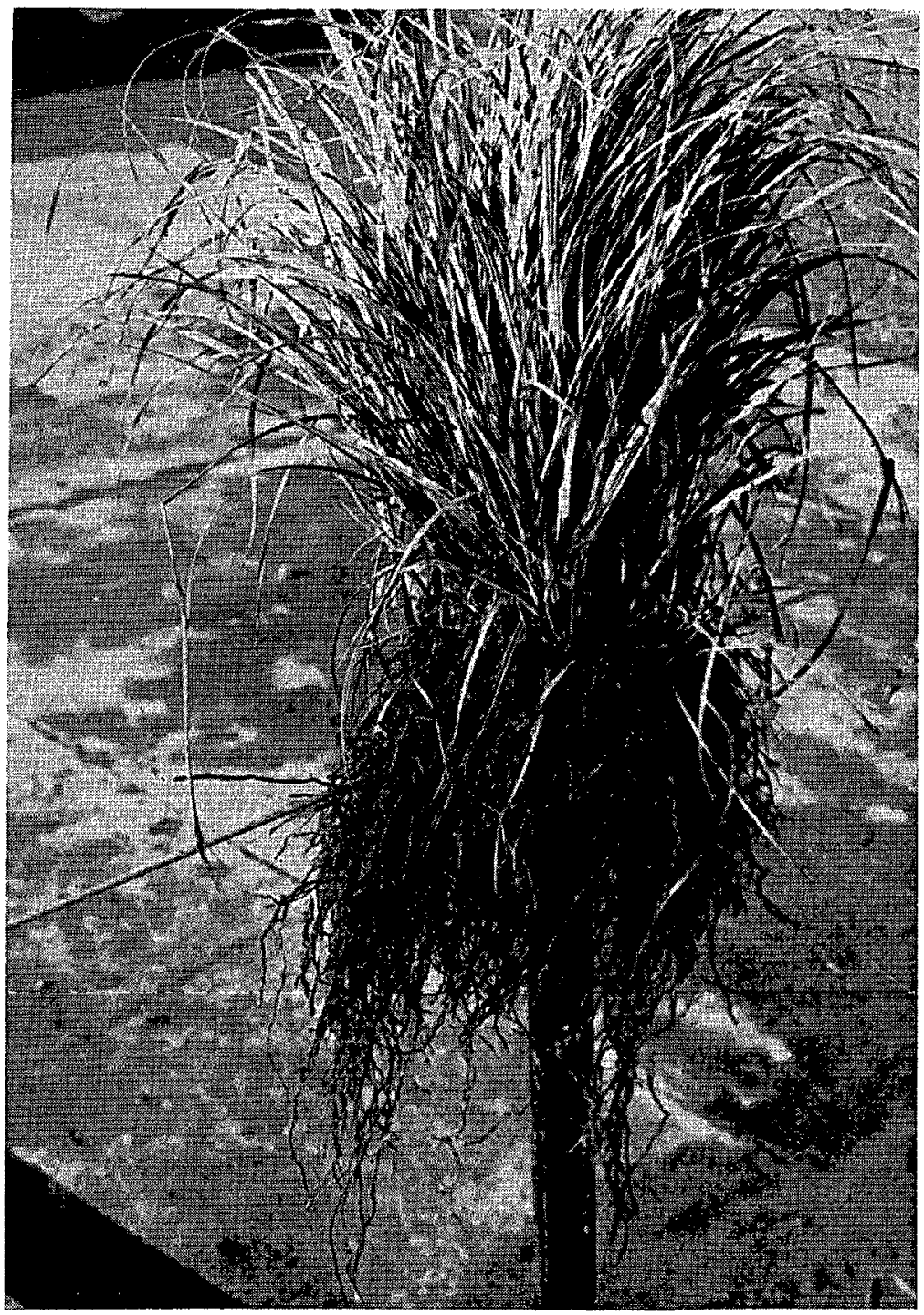

FтG. 1: A plant of Australian sedge showing its tussock-forming growth habit and robust root system. 
TABLE 1: SEED WEIGHT (MG) AND PERCENTAGE GERMINATION

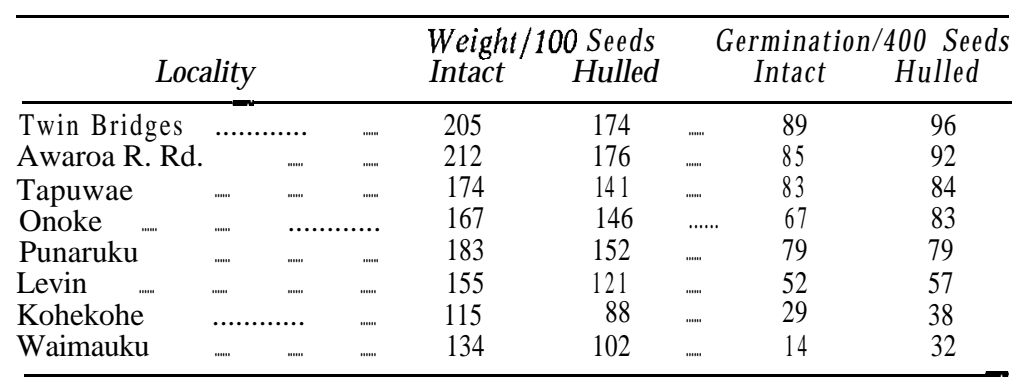

\section{REPRODUCTION}

Reproduction is entirely by seed and plants produce one crop each year. Floral initiation takes place in late summer or autumn and young inflorescences are visible in dissected shoots in mid-winter, though they do not emerge until the following spring. Peak flowering occurs in December/ January and utricles begin to fall in late summer, the seed being liberated by decay of the utricle. Plants raised outdoors at Lincoln flower in the second year following germination, but, in the field, flowering begins later still.

Flowers are wind-pollinated and plants appear to be self-fertile, though perhaps not exclusively self-pollinated. Excellent seed set has been observed. An average-sized plant (diameter 12 in., circumference 39 in.) from the Levin infestation yielded 116 flowering stems, averaging 12 female spikes per stem and 20 seeds per spike, giving an estimated total of 27,840 seeds.

The germinative capacity of seed is high and it can be 'improved in the laboratory by removing the utricle (Table 1). Somewhat lower seed weights and germination are apparent in seed harvested from very drought-prone areas. Germination in the field has not been followed closely, but it is thought to take place only in spring and early summer.

\section{DISPERSAI}

The seed of Australian sedge is relatively heavy and the utricle is not endowed with special mechanisms to assist dispersal. Most of the seed shed falls within 12 in. from the edge of the canopy. Some is carried for longer distances by strong gusts of wind or on the feet of livestock. In this way, isolated plants become established, gradually developing into colonies which ultimately coalesce if conditions 
TABLE 2: DISTRIBUTION OF SOIL-BORNE SEED (AUGUST 1966) Total Number in 40 one-inch Cores

\begin{tabular}{|c|c|c|c|c|c|c|c|c|c|}
\hline & $\begin{array}{c}\text { Depth } \\
\text { (in.) }\end{array}$ & & $\begin{array}{l}\text { Parau } \\
\text { Plump } \\
\text { Seed }\end{array}$ & $\begin{array}{l}\text { Clay } \\
\text { Empty } \\
\text { Seed }\end{array}$ & $\begin{array}{l}\text { Waimauku } \\
\text { Germinated } \\
\text { Seeds }\end{array}$ & & $\begin{array}{l}\text { Red Hill } \\
\text { Plump } \\
\text { Seed }\end{array}$ & $\begin{array}{l}\text { Sand } \\
\text { Empty } \\
\text { Seed }\end{array}$ & $\begin{array}{c}\text {-Kohekohe } \\
\text { G erminated } \\
\text { Seeds }\end{array}$ \\
\hline O-1 & \multirow{3}{*}{$\ldots . .}$. & . & 182 & 85 & 25 & $\ldots$ & 535 & 123 & 7 \\
\hline $1-2$ & & ..." & 8 & 9 & 3 & . & 29 & 34 & 1 \\
\hline $2-3$ & & $\ldots$ & 20 & 4 & 3 & . & 9 & 1 & - \\
\hline
\end{tabular}

permit. Infested hay crops may assist long-range dispersal, but seed mixtures contaminated with Australian sedge are a more effective means of distribution.

Seed counts taken from dense infestations on two contrasting soils show that most of the seed is contained in the top inch of soil (Table 2). It also seems that the seed deteriorates fairly rapidly once it is shed.

\section{DISTRIBUTION}

The distribution of the Australian sedge in the North Island, based on records received up to August, 1967, is shown in Fig. 2 (there is no record of this plant in the South Island). The distribution pattern suggests an apparent preference for northern New Zealand in what is commonly called the "Paspalum zone". Although the distributions of paspalum and Australian sedge broadly coincide, this is largely circumstantial, since the weed is a known impurity of imported paspalum seed (Molloy and Edgar, 1967). Unlike paspalum, the spread of Australian sedge is not likely to be restricted by temperature, and it should be emphasized that much North Island hill country lies well within its climatic tolerance.

The pattern on the ground is one of dense patches, scattered individuals, or small isolated colonies, mainly on rolling. lands and hills.

\section{ENVIRONMENTAL RELATIONSHIPS}

The environment of the Australian sedge is considered from two viewpoints: factors which directly stimulate its establishment and growth ; factors which contribute indirectly by retarding the growth of its potential competitors. To investigate these points, several severe infestations in northern New Zealand were studied (Fig. 3). Features of each site are shown in Appendix A. 


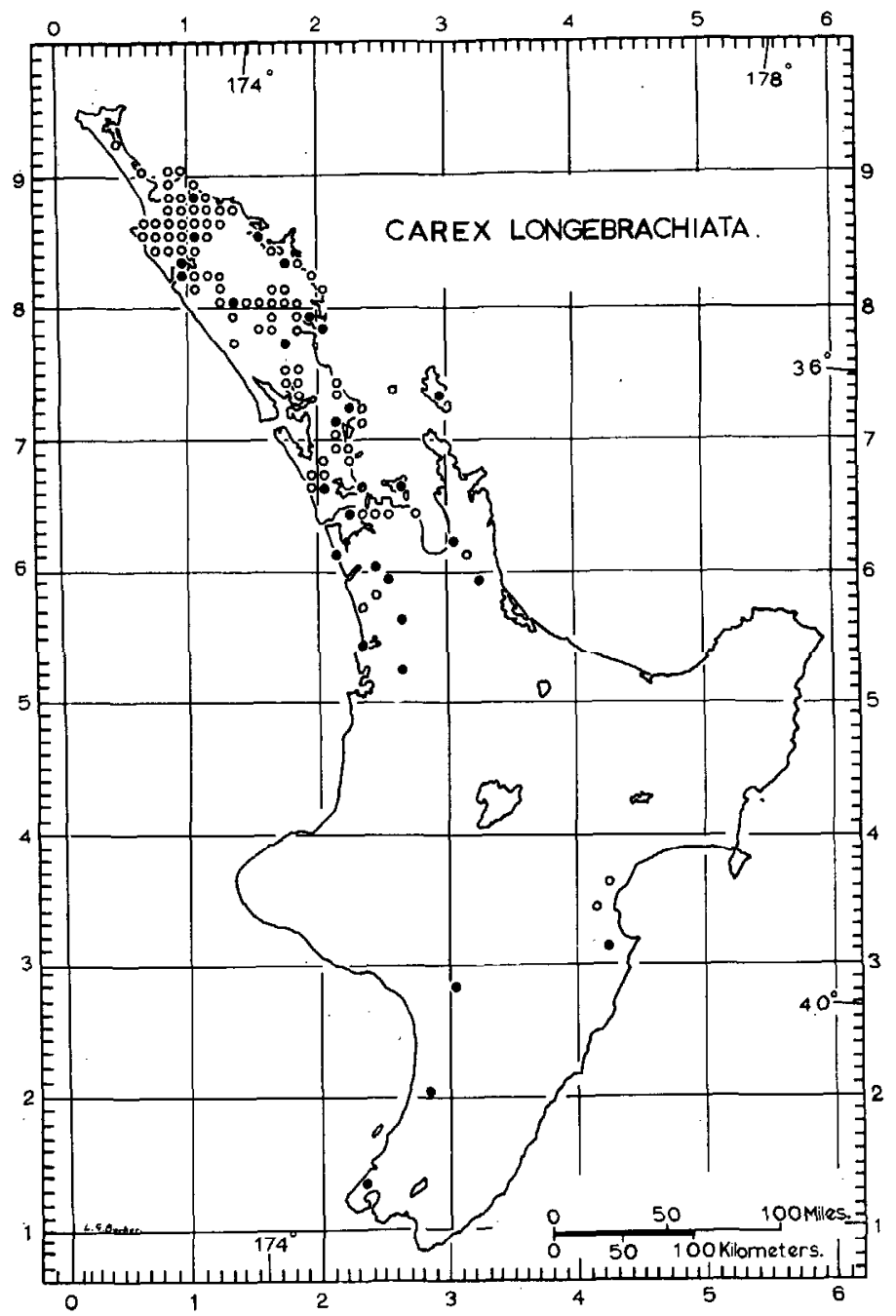

Fig. 2: Distribution of Australian sedge in the Noth Isad

Grid lines are spaced at 100,000-yd intervals, and bear the numbers of the National Grid as they appear on N.Z.M.S. maps. The margins of the map show a further subdivision into 10,000-yd intervals. Symbols refer to presence of any number of individuals in 10,000-yd grid squares. Some coastal grid squares cover part land, part sea. Where a symbol for such a square is in contact with the coastline, it refers to presence on the mainland, not on an outer-lying island. Clear sections of the map indicate that the species is absent or the area has not been examined.

- Presence of Carex longebrachiata is confirmed by a voucher or herbarium specimen.

O Carex longebrachiata reliably reported to be present. (cf. Wardle and MacRae, 1966.) 


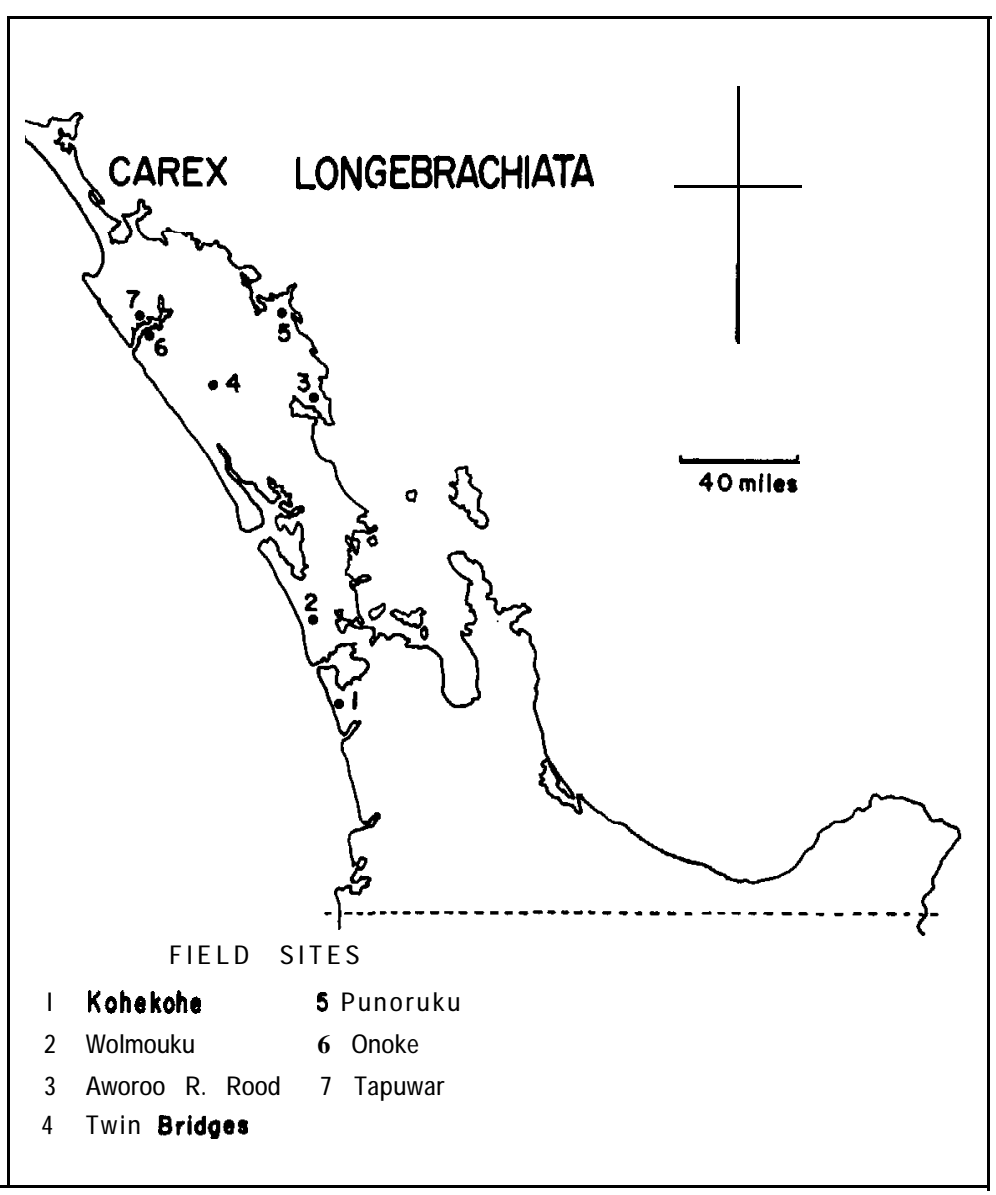

Fig. 3: Map showing the location of infestations studied in some detail.

Citmate

The climate of northern New Zealand is noted for warm humid summers, relatively mild winters and a plentiful rainfall (de Lisle and Kerr, 1964). The general suitability of this climate for sedge growth is supported by the fact that $40 \%$ of the New Zealand sedge flora will grow north of A uckland. On the other hand, some of these species (e.g., Carex lucida C. comans) grow equally well in Southland, and plants of Australian sedge have survived two winters 
at Lincoln with no ill effects. High humidities and warm temperatures assist seedling establishment, vegetative growth and reproduction, but continued high temperatures can retard growth and often result in severe bleaching of sedge foliage.

Perhaps the key climatic factor for potential competitors is the variability of rainfall. A ccording to Coulter (1965), rainfall deficiencies are more frequent in northern $\mathrm{New}$ Zealand than the average rainfall suggests. Short- and longterm droughts are not infrequent and are usually accompanied by high light intensities and high temperatures. Under these conditions, pasture growth can be severely restricted, especially in closely-grazed swards.

\section{SOILS}

Australian sedge grows on a variety of soils derived from an equally varied assortment of parent material. An analysis of the topsoils of seven infestations demonstrated wide ranges in chemical and physical properties, though the general level of chemical fertility was somewhat higher than expected (Appendix B). Moreover, a comparison of the topsoil properties of clean and infested land on two contrasting soils showed that infested soils can be just as fertile, if not better, than sedge-free soils (Appendix C).

All these soils, however, require a generous application of fertilizer if competing pasture is to attain its full production potential (the fertilizer requirements of similar soils are described by During, 1967). But nutrient status is probably secondary to soil moisture as a major soil factor imiting this attainment. The average to sub-average values for available moisture in the topsoils examined in this study indicate that soil moisture stresses are likely to occur during periods of infrequent summer rainfall. The relatively shallow-rooted pasture species will be adversely affected since they tend to use water extravagantly under hot conditions (Mitchell, 1963), whereas A ustralian sedge with its stronger, deeper roots will be less affected.

\section{Associated Species}

A clearer picture of the environment of the Australian sedge can be derived from the composition of infested swards. Most are definitely poor, consisting mainly of inferior pasture species, weeds and miscellaneous plants of debatable usefulness (Table 3, Appendix D). 
TABLE 3: SPECIES COMMONLY ASSOCIATED WITH AUSTRALIAN SEDGE

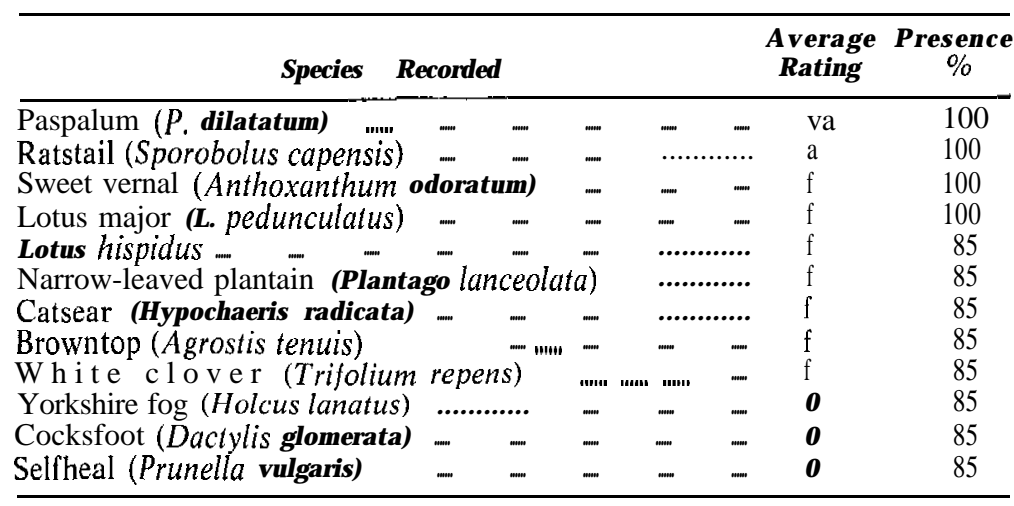

Note: va=very abundant; $a=$ abundant; $f=$ frequent; o=occasional.

\section{ANAGEMENT}

There seems little doubt that seasonal overgrazing of inferior swards has greatly aided the spread of Australian sedge. Under the common practice of set-stocking, such swards can be subject to intense pressure during winter or dry spells in summer, even from comparatively low stock numbers. Moreover, once properly established, Australian sedge is generally unpalatable to livestock. Transitions between clean and infested land are abrupt and conspicuous, illustrating its limited dispersal ability and, in some cases, the difficulty which it has establishing in vigorous pasture.

Within limits, the composition of the competing sward is perhaps not as important as the treatment which it has received over the years. This is shown in Table 4, where clean and infested swards on two contrasting soils are compared. The clean pasture at Kohekohe is essentially a high-producing ryegrass/ white clover sward, whereas the one at Waimauku is a lower-producing, crested dogstail/ white clover sward. Both are effective in keeping Australian sedge out, but observations suggest that inferior swards may be less effective.

\section{ERADICATION AND CONTROL}

Trials conducted over the past decade have been reviewed by Honore (1966) and Merry (1967). A ustralian sedge 
TABLE 4: DOMINANT SPECIES OF CLEAN AND INFESTED LAND

Mean Number of Cover Hits/100 Points

\begin{tabular}{|c|c|c|c|c|c|c|c|c|}
\hline \multirow{2}{*}{\multicolumn{3}{|c|}{ Species }} & \multicolumn{3}{|c|}{ Infested } & \multicolumn{3}{|c|}{ Clean } \\
\hline & & & & V aimauku & Kohekohe & & Waimauku & Kohekohe \\
\hline Australian sed & & ...." & $\ldots$ & 31.5 & 56.0 & $\ldots$ & - & - \\
\hline Paspalum & $\ldots \ldots$ & & ......... & 20.2 & 7.6 & InI" & 10.5 & 2.7 \\
\hline Ratstail ..... & ........ & $\ldots .$. & $\ldots$ & 9.0 & 7.7 & int & 0.4 & 3.5 \\
\hline Meadow ricegi & rass & $\ldots$ & $\ldots$ & 4.0 & 9.5 & in! & 8.7 & 3.2 \\
\hline Lotus spp. (2) & & $\ldots$ & $\ldots$. & 5.0 & 2.0 & . & 0.7 & 2.3 \\
\hline Cocksfoot & ..... & $\ldots$ & $\ldots$ & 12.5 & 2.2 & "n!" & - & - \\
\hline Suckling clove & & ......... & . . & - . & - & . . & 5.0 & 3.0 \\
\hline Subterranean & clove & & $\ldots$ & 0.1 & 0.1 & ..." & 11.7 & 6.2 \\
\hline Sweet vernal & ...... & _ & $\ldots$ & 4.0 & 3.5 & nat & 13.7 & 11.0 \\
\hline Crested dogsta & & - & ..." & 一 & 0.3 & ma! & 23.5 & 2.5 \\
\hline White clover & 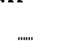 & ........ & $\ldots$ & 3.5 & 7.2 & $\ldots$ & 24.2 & 29.0 \\
\hline Ryegrass-spp. & ...... & ....... & $\ldots$ & - & 7.2 & ."m!" & 12.2 & 58.7 \\
\hline
\end{tabular}

seems to be very sensitive to disturbance, and eradication is possible by cultivation, where this is feasible, provided it is followed by sound pasture management and vigilant grubbing or "spot" spraying of fresh seedlings. In addition, isolated plants and small colonies can be grubbed out quite successfully. Eradication by the use of herbicides such as 2,2-DPA is technically possible, but only at uneconomic rates of application and not without extensive pasture damage.

So far, attempts to control this weed have been only partially effective. An extremely hot fire followed by oversowing and topdressing is reported to be reasonably successful, and likewise cutting light infestations with a rotary slasher followed by sward improvement. However, regrowth and seedling invasion can be perennial problems. There is little information on repeated burning or cutting of heavy infestations in conjunction with sward improvement.

Chemical control using esters of 2,4-D at economic rates is also reasonably successful. The best results are achieved by spraying regrowth after burning or cutting, followed by oversowing and topdressing to strengthen the sward, then annual "spot" spraying of regrowth and seedlings.

Biological control of this weed is a remote possibility. As far as is known, the species is remarkably free of plant pathogens and phytophagous insects. 


\section{SUMMARY AND CONCLUSIONS}

To summarize, Australian sedge with its deeply-rooting, tussock-forming habit and unpalatable foliage is well suited to become a serious weed in overgrazed, inferior pastures, particularly on hill country. Its chief weaknesses are its inability to disperse rapidly over long distances and its comparatively slow growth; two reasons accounting for its late recognition as a noxious weed. Further, seedling establishment is a critical phase in its life history.

The unique distribution of this weed is due almost entirely to past sowings of infested paspalum seed, and its frequency on the ground is determined by the kind of treatment the resulting swards have received. At present, Australian sedge is still coming into the country in imported paspalum seed, but the new quarantine regulations being prepared should prevent its further entry.

Although heat-fearing and moisture-loving like most species of Carex, Australian sedge is reasonably well attuned to the environment of northern New Zealand, though it is by no means restricted to it. The same environment, on the other hand, can impose severe restrictions on the growth of its potential competitors, namely the more useful pasture species.

Once firmly established, Australian sedge is both difficult and costly to eradicate, especially on hilly country. Previous research indicates that chemical and/ or burning and cutting treatments yield a fair measure of control, though repeated treatments are often necessary. This aspect of control should be investigated thoroughly until a more effective and reliable method is obtained. At the same time, more emphasis is needed on management aspects following these pre-treatments.

Our current research programme is designed with these thoughts in mind and it is anticipated that the results obtained will be directly applicable to farms.

\section{ACKNOWLEDGEMENTS}

Thanks are due to L. G. Barker, B. Dun, E. N. Honore and N. Kimpton for assistance in the field ; to D. S. Rickard for arranging soil analyses; to Mrs M. E. H. Johnston for arranging seed counts and germination tests; to J. E. Cox for a description of the Rangiora soil and advice on soils; to the Fields Superintendent and farm advisory officers of the Auckland district for information on the distribution 
of Australian sedge; to staff of Botany Division, D.S.I.R., for distribution data and advice; and to farmers for their co-operation. Figures 2 and 3 were drawn by L. G. Barker.

\section{REFERENCES}

Coulter, J. D. 1965: N.Z. G eographer, 22: 22-34.

During, C. 1967: Proc. 29th Cont. N.Z. Grassl. Ass., 15-23.

Honore, E. N. 1966: Proc. 19th N.Z. Weed and Pest Control Conf., 107-9. de Lisle, J. F.; Kerr, I. S. 1964: N.Z. Met. Serv. Misc. Pub. 115 (2): 14 pp. Merry, D. M. E. 1967: N.Z. J. Agric., 114 (4): 44-7.

Mitchell, K. J. 1963: Proc. N.Z. Inst. Agric. Sci., 9: 80-96.

Molloy, B. P. J.; Edgar, E. 1967: N.Z. J. Agric., 114 (4): 41-4.

Saunders, W. M. H. 1965: N.Z. J. agric. Res., 8: 30-57.

Wardle, P.; MacRae, A. H. 1966: N.Z. J. Bot., 4: 114-31. 
PROCEEDINGS N.Z. GRASSLAND ASSOCIATION

APPENDIX B

SOIL PROPERTIES OF SEDGE JNFESTATIONS

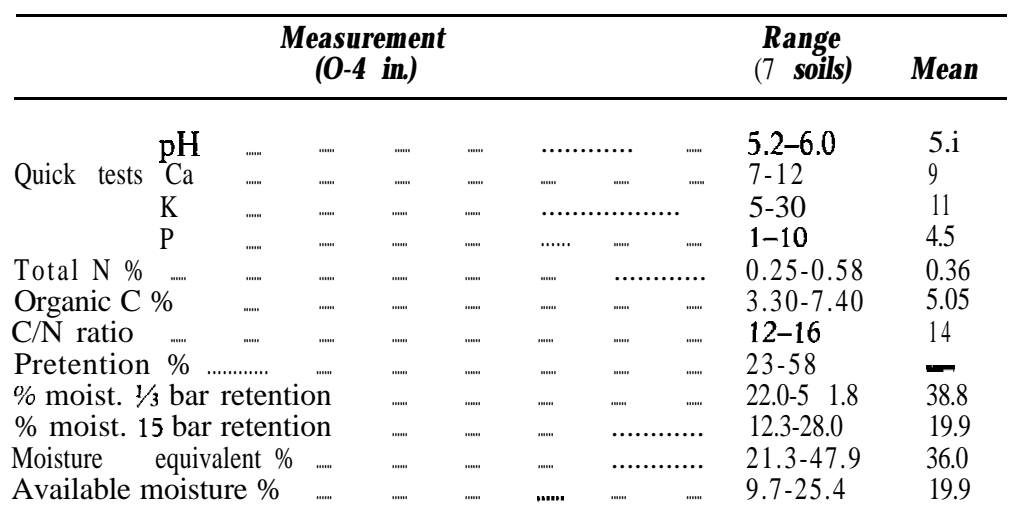

Note: Percentages calculated on an oven-dried weight basis. $\mathrm{P}$ retentions based on Saunders (1965).

APPENDIX ..C

SOIL PROPERTIES OF CLEAN AND INFESTED LAND

\begin{tabular}{|c|c|c|c|c|c|c|c|c|}
\hline \multicolumn{3}{|c|}{$\begin{array}{l}\text { M easurement } \\
(0-4 \text { in.) }\end{array}$} & \multicolumn{3}{|c|}{$\begin{array}{c}\text { Parau Clay - } \\
\text { Waimauku } \\
\text { Infested Clean }\end{array}$} & \multicolumn{3}{|c|}{$\begin{array}{l}\text { Red Hill Sand - } \\
\text { Kohekohe } \\
\text { Infested Clean }\end{array}$} \\
\hline $\mathrm{pH}$ & . & ntu+ & mutu & 5.5 & 5.2 & & 5.8 & 5.9 \\
\hline \multirow[t]{3}{*}{ Quick tests } &. & (n+in' & .‥" & 11 & 7 & & 7 & 5 \\
\hline & & ....... & ...... & 7 & 6 & & 7 & 11 \\
\hline & .. & ........ & ........ & 4 & 3 & $\ldots . . . \cdot$ & 9 & 8 \\
\hline Total N \% & $\mu$ & ...". & (n) & 0.36 & 0.44 & & 0.27 & 0.25 \\
\hline Organic C \% & . & 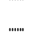 & ..... & 5.81 & 6.22 & & 3.44 & 3.11 \\
\hline $\mathrm{C} / \mathrm{N}$ ratio & the & ....... & ...." & 16 & 14 & . & 13 & 12 \\
\hline$\%$ moist. $1 / 3$ bar rete & tion & ...... & ....... & 44.4 & 41.0 & ..... & 22.4 & 17.2 \\
\hline$\%$ moist. 15 bar rete & tion & ........ & $\ldots$ & 24.5 & 23.3 & & 12.7 & 10.1 \\
\hline Moisture equivalen & & ....... & $\ldots$ & 41.6 & 37.8 & 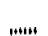 & 21.7 & 17.5 \\
\hline Available moisture & & ."' & ."'n" & 19.9 & 17.7 & .1....' & 9.7 & 7.1 \\
\hline
\end{tabular}

Note: In this study, available moisture is defined as the difference between measured wilting point (15 bar retention) and estimated field capacity $(1 / 3$ bar retention). 
APPENDIX A

AUSTRALIAN SEDGE INFESTATIONS: SITE FEATURES

\begin{tabular}{|c|c|c|c|c|c|c|c|c|c|}
\hline \multicolumn{2}{|l|}{ Locality } & & Grid. R ef. & Aspect & $\begin{array}{l}\text { Slope } \\
\text { (deg.) }\end{array}$ & $\begin{array}{l}\text { Rainfall } \\
\text { (in.) }\end{array}$ & Soil & Soil Group & Parent Material \\
\hline Kohekohe & & $\ldots$ & N47/165181 & $\mathrm{NE}$ & 25 & $45-50$ & Red Hill* & $\begin{array}{l}\text { Northern yellow-brown } \\
\text { sands }\end{array}$ & $\begin{array}{l}\text { Weathered sand } \\
\text { and pumice }\end{array}$ \\
\hline Waimauku & & $\ldots \ldots$ & .N41/034695 & $\mathrm{NE}$ & 20 & $50-55$ & Parau" & $\begin{array}{l}\text { Northern brown-granular } \\
\text { clays }\end{array}$ & $\begin{array}{l}\text { Andesitic tuff } \\
\text { and sediments }\end{array}$ \\
\hline Awaroa R.Rd & & $\ldots \ldots$ & $\mathrm{N} 20 / 886978$ & $\mathrm{NW}$ & 34 & $60-70$ & Te Ranga* & $\begin{array}{l}\text { Northern yellow-brown } \\
\text { earths (skeletal) }\end{array}$ & Greywacke \\
\hline Twin Bridges & & . & N19/368064 & NW & 30 & $60-70$ & Waimatenui* & $\begin{array}{l}\text { Northern brown-granular } \\
\text { clays }\end{array}$ & $\begin{array}{l}\text { Andesite and } \\
\text { andesitic tuff }\end{array}$ \\
\hline Punaruku & $\ldots . .$. & & N16/818395 & NE & 15 & $60-70$ & Rangiora & $\begin{array}{l}\text { Northern yellow-brown } \\
\text { earths (podzolized) }\end{array}$ & $\begin{array}{l}\text { Red-weathered } \\
\text { greywacke }\end{array}$ \\
\hline Onoke...... & . & . & N14/943302 & $\mathrm{NE}$ & 12 & $50-55$ & Waiotira* & $\begin{array}{l}\text { Northern yellow-brown } \\
\text { earths }\end{array}$ & Sandstone \\
\hline Tapuwae & & $\ldots . .$. & $\mathrm{N} 14 / 946384$ & NW & 20 & $55-60$ & Autea* & $\begin{array}{l}\text { Northern yellow-brown } \\
\text { earths }\end{array}$ & $\begin{array}{l}\text { Sandstone/ } \\
\text { mudstone }\end{array}$ \\
\hline
\end{tabular}

* Provisional field identification. Rainfall estimates based on de Lisle and Kerr (1964) 


\section{APPENDIX D}

List of species found in two or more of the seven infestations of Australian sedge examined. Common names conform to the list of standard common names prepared by the New Zealand Weed and Pest Control Conference (Inc.) (in press).

(1) Found in 6 infestations:

Scotch thistle

Danthonia

(2) Found in 5 infestations:

Indian doab

Purple cudweed

(3) Found in 4 infestations:

funcus tenuis

Toad rush

Cyperus brevifoliu

Crested dogstail

Hawkbit

Tarweed

Australian speedwell

(4) Found in 3 infestations:

funcus australis

Meadow ricegrass

Chewings fescue

Ryegrass

Suckling clover

Hawksbeard

Manuka

Cirsium vulgare

Notodanthonia spp.

Cynodon dactylon

Gnaphalium purpureum

funcus bufonius

Cynosurus cristatus

Leontodon taraxacoides

Parentucelliu viscosa

Veronica plebeja

Microlaena stipoides

Festuca rubra var. commutata

Lolium sp

Trifolium dubium

Crepis capillaris

Leptospermum scoparium

(5) Found in 2 infestations:

Carex lucida

Shivery grass

N.Z. plume grass

Subterranean clover

Dandelion

Clustered dock

Bracken

Yarrow

Oxalis corniculata

Creeping buttercup

Sweet brier

Blackberry

Woodrush

Cleavers

Centaury

Pennyroyal

Briza minor

Dichelachne crinita

Trifolium subierraneum

Taraxicum officinale

Rumex conglomeratus

Pteridium aquilinum var. esculentum

Achillea 'millefolium

Ranunculus repens

Rosa rubiginosa

Rubus fruticosus agg.

Luzula campestris

Galium aparine

Centaurium erythraea

Mentha pulegium

A further 24 species occurred in only one infestation. 


\section{DISCUSSION}

(a) Does the seed of species retain viability in passing through the animal?

(b) Is the plant eaten when the seeds are viable?

P. J. Rumrall: WC have no definite information on the role of the animal in seed dispersal. The inflorescence is unpalatable and since the seed is relatively smooth and heavy it is likely that very little would lodge in the pasture canopy to be ingested.

Are seedling plants eaten by stock?

G. L. B. Cumberland: Yes, seedling plants are eaten by stock- both sheep and cattle-but only under heavily-stocked conditions.

Is anything known about the length of time seed remains viable in soil?

B. P. I. Molsor: This aspect has not been studied in great detail, but the poor germination of soil-borne seed shown in Table 2 suggests that the life of the seed is very short.

Has any work been done in control with rotary slashing techniques together with oversowing and topdressing? Do parent plants recover from slashing?

Mr CUMBerLand: No trial work has been conducted specifically to look at rotary slashing effects. Here, though, it must be emphasized that in dense stands burning is necessary to rid the area of a heavy cover of sedge litter whether or not it has been slashed. The litter left after slashing, or even after spraying, can remain relatively undecomposed on the ground for 6 to 12 months. Such litter prevents any pasture establishing, however much pasture seed and topdressing the area receives. Slashing within half-an-inch of the ground will bodily knock some carex tussocks out of the ground such treatment will kill these parent plants. Simply removing the foliage above the tillering points by slashing does not appear to kill the parent plant.

Would Mr Cumberland give some information on chemical control, time of application, rate and types used?

Early work - much of it conducted by the Advisory Division of the Department of Agriculture-found that $40 \mathrm{lb}$ of 2,2-DPA per acre killed a large proportion of carex plants. Isocil, diquat, paraquat and mixtures of these with 2,2-DPA have also been tried with moderate success. Most workers have agreed that a burn increases the effect of chemical applications. More recent work has shown that rates of 2,4-D as low as $4 \mathrm{lb}$ a.i. per acre for a reasonable kill, and $2 \mathrm{lb}$ a.i. per acre for a good burn, are required. The octyl ester of 2,4-D has given more marked and quicker effects than other formulations.

Has any of the work already done in the Whangarei County been followed up with soda salt additives?

Mr Cumberland: Not to my knowledge. 
Has Mr Somerville tried 12 wethers per acre on this sedge?

No. We are not faced with this problem to any great extent. We have tried cattle. The first essential is to burn, and then some success with cattle can be achieved. Raising fertility and pasture vigour is also essential but sedge is often in inaccessible places.

On steep unploughable hill country, is there a practical solution to controlling sedge and bringing country in?

Mr Cumberdand: An eradication programme should be practicable even on steep hill country through combinations of burning, topdressing, coversowing, spot spraying, grubbing and controlled stocking. The plant is a slow spreader and if seeding can be restricted for at least two years it seems that very little viable seed remains to germinate. Research into this aspect has now begun on hill country on Waiheke Island.

Would Dr Molloy comment on the possibility of this weed being transferred in the fleece of sheep?

Seed dispersal in fleece wool is very unlikely, except perhaps by chance. Seeds mixtures contaminated with Australian sedge are considered the chief means whereby this weed has been distributed around the countryside. 